\title{
Pengaruh Model Visualization, Auditory, Kinestetic (VAK) Berbantuan Media Gambar Terhadap Hasil Belajar IPA
}

\author{
Ni Wayan Wahyuni ${ }^{1 *}$ Nyoman Kusmariyatni ${ }^{2}$ I Nyoman Murda ${ }^{3}$
}

${ }^{123}$ Prodi Pendidikan Guru Sekolah Dasar, Universitas Pendidikan Ganesha, Indonesia

\section{A R T I C L E I NFO Article history: Received 18 Desember 2019 \\ Received in revised form 30 Desember 2019 \\ Accepted 15 Januari 2020 \\ Available online 20 \\ Februari 2020

Kata Kunci:
(VAK), Media gambar, hasil
belajar IPA.

Keywords:

(VAK), picture media,

students' result of study

\begin{abstract}
A B S T R A K
Penelitian ini bertujuan untuk mengetahui perbedaan model pembelajaran Visual, Auditory, Kinestetik (VAK) berbantuan media Gambar dan model pembelajaran tanpa model terhadap hasil belajar siswa kelas V SD di Gugus 2 Banjarangkan. Jenis penelitian ini adalah quasy exsperiment. Populasi penelitian ini yaitu siswa kelas $\mathrm{V}$ SD Gugus 2 Banjarangan Kabupaten Klungkung tahun pelajaran 2017/2018, sebanyak 91 siswa. Sampel penelitiannya yaitu kelas V di SD Negeri 2 Banjarangkan sebagai kelompok eksperimen sebanyak 32 orang siswa dan kelas $\mathrm{V}$ di SD Negeri 3 Banjarangkan sebagai kelompok kontrol sebanyak 31 orang siswa. Pengumpulan data dalam penelitian ini dilakukan dengan metode tes, sedangkan instrumen yang digunakan adalah tes hasil belajar (tes pilihan ganda). Data yang diperoleh selanjutnya dianalisis dengan teknik menggunakan analisis statistik deskriptif dan statistik inferensial. Hasil penelitian menunjukkan skor rerata data hasil belajar siswa kelas eksperimen lebih dari hasil belajar kelas kontrol yaitu $23,88>18,95$. Hasil perhitungan uji hipotesis dengan uji-t, diperoleh thitung $=$ 7,8687 dan tabel dengan $\mathrm{db}=61$ dan taraf signifikansi $5 \%$ adalah 1,999. Jika dibandingkan akan terlihat bahwa $t_{\text {hitung }}>t_{\text {tabel }}(7,8687>1,999)$. Sehingga dapat disimpulkan bahwa terdapat perbedaan yang antara siswa yang dibelajarkan
\end{abstract} dengan model pembelajaran Visual, Auditory, Kinestetik (VAK) berbantuan media Gambar dan siswa yang dibelajarkan dengan model pembelajaran tanpa model pada siswa kelas V SD di Gugus 2 Banjarangkan Kabupaten Klungkung.

\section{A B S T R A C T}

This study aimed to determine the differences in Visual, Auditory, Kinesthetic (VAK) learning models assisted by Image media and modelless learning models on the learning outcomes of fifth grade elementary school students in SD di Gugus 2 Banjarangkan. This research was quasy experiment. The population of this research was the fifth grade students of SD di Gugus 2 Banjarangkan Kabupaten Klungkung in 2017/1018 academic year, as many as 91 students. The research sample was fifth grade students of SD Negeri 2 Banjarangkan as an experimental group consists of 32 students and fifth grade students in SD Negeri 3 Banjarangkan as a control group consist of 31 students. Data collection in this study was carried out by the test method, while the instrument used was the learning achievement test (multiple choice test). The data obtained were analyzed by descriptive statistical analysis and inferential statistics. The results showed the average score of student learning outcomes of the experimental class was more than the control class learning outcomes 23.88> 18.95. The calculation result of the hypothesis test with the $t$-test were tcount $=7.8687$ and ttable with $d b=61$ and a significance level of $5 \%$ was 1.999. If it was compared, it will be seen that tcount $>$ ttable (7.8687> 1.999). So, it can be concluded that there are differences between students who are taught with Visual, Auditory, Kinesthetic (VAK) learning models assisted by Image media and students who are taught with modelless learning models in fifth grade elementary school students in SD di Gugus 2 Banjarangkan Kabupaten Klungkung.

Copyright (@) Universitas Pendidikan Ganesha. All rights reserved.

\section{Pendahuluan}

Perkembangan teknologi yang sangat pesat pada saat ini menuntut adanya Sumber Daya Manusia yang berkualitas dan mampu bersaing. SDM yang mampu bersaing di dunia adalah SDM yang berpendidikan. Sekolah sebagai salah satu pelaksanaan proses pembelajaran diharapkan dapat melaksanakan pembelajaran dengan baik. Proses pembelajaran yang baik adalah proses pembelajaran yang dapat membuat siswa berperan aktif dalam pembelajaran. Guru sebagai salah satu tenaga pendidik profesional dengan tugas utama mendidik,membimbing,mengarahkan,melatih dan mengevaluasi siswa pada pendidikan di jalur formal. Dalam proses pembelajara di sekolah siswa diajarkan berbagai macam disiplin ilmu salah satunya IPA (Ilmu Pengetahuan Alam). Dalam Observasi yang pernah dilakukan dalam

\footnotetext{
${ }^{1}$ Corresponding author.

E-mail addresses: wayanwahyuni03@gmail.com¹, nyoman.kusmariyatni@undiksha.ac.id² inyoman.murda@undiksha.ac.id ${ }^{31}$
} 
proses pembelajaran IPA kelas V SD di Gugus 2 Banjarangkan Kabupaten Klungkung (wawancara, pengamatan dan pencatatan dokumen) yang telah dilakukan pada tanggal 4 Januari 2018, banyak siswa yang kurang berminat dan kurang antusias dalam mengikuti proses pembelajaran IPA.

Menurut Susanto (2013:167), Sains atau IPA adalah usaha manusia dalam memahami alam semesta melalui pengamatan yang tepat pada sasaran, serta menggunakan prosedur, dan dijelaskan dengan penalaran sehingga mendapatkan suatu kesimpulan.

Selain itu, banyak siswa pula yang belum menguasai dan memahami materi yang sudah diajarkan oleh guru. Siswa tidak terlibat aktif dalam proses pembelajaran, Hal ini bisa mengakibatkan siswa jadi tidak bisa memahami konsep yang sedang mereka pelajari dan akan berdampak juga terhadap hasil belajar mereka. Tinggi rendahnya hasil belajar siswa dapat dipengaruhi oleh berbagai faktor diantaranya adalah model maupun strategi pembelajaran yang digunakan oleh guru, media pembelajaran yang digunakan oleh guru ketika mengajar, dari segi perekonomian dalam keluarga siswa, dan masih banyak lagi faktor-faktor yang lainnya. Dalam mengajar guru hanya menyampaikan materi yang ada dalam buku, jarang guru mau menyesuaikan standar isi yang ingin dicapai dengan isi buku yang digunakan. Kadang di lapangan standar isi yang ingin dicapai tidak sesuai dengan isi buku yang digunakan. Selain itu, dalam mengajar jarang dan bahkan tidak ada sama sekali penggunaan media pembelajaran yang relevan dengan materi ajar. Hal tersebut menyebabkan siswa berfikir abstrak.

Banyak model pembelajaran yang telah dikembangkan dalam menunjang proses pembelajaran dengan harapan pencapaian tujuan instruksional yang optimal, tetapi penggunaan model pembelajaran yang tidak ditunjang dengan kehadiran media dalam pembelajaran kurang memaksimalkan proses pembelajaran sehingga hasil belajar siswa belum tercapai secara optimal. Setelah dicermati dan dianalisis pola pembelajaran yang diterapkan oleh guru di Gugus 2 Banjarangkan adalah model pembelajaran tanpa model. Pembelajaran tanpa model ini telah dipergunakan sebagai alat komunikasi lisan antara guru dengan siswa dalam proses pembelajaran. Pembelajaran tanpa model menyampaikan informasi atau pengetahuan secara langsung atau utuh dari pikiran pengajar ke pikiran si pemelajar (siswa), dan proses pembelajaran berpusat pada guru (teacher centered).

Penyampaian informasi secara langsung kepada siswa tanpa disertai dengan keterlibatan siswa sebagai individu yang memiliki pengetahuan awal yang akan disempurnakan oleh guru dalam kegiatan pembelajaran, kurang membuat pembelajaran menjadi bermakna karena guru mempunyai peranan penting dalam menggali pengetahuan awal siswa dan memadukannya dengan pengetahuan baru sehingga siswa tidak mengalami miskonsepsi terhadap hal-hal yang telah diketahui sebelumnya. Maka dalam membelajarkan siswa, guru harus mampu memilih model pembelajaran yang mampu memadukan pengetahuan awal siswa dengan pengetahuan baru untuk menyempurnakan pengetahuan awal siswa sehingga dalam proses pembelajaran siswa dapat berperan aktif dan pembelajaran berpusat pada siswa (student centered). Salah satu model pembelajaran yang diinovasikan dalam membelajarkan siswa dari pengetahuan awal menjadi bentuk aplikasi pengetahuan baru dengan mengeksplorasi dan mereduksi pengetahuan awal adalah model Pembelajaran Visualization, Auditory, Kinestetic yang sering disebut VAK.

(Adnyani 2014) Dalam model pembelajaran Visualization, Auditory, Kinestetic (VAK) ini guru memanfaatkan tiga kemampuan yang telah dimiliki dalam diri siswa sendiri sehingga diharapkan dapat memaksimalkan proses belajar siswa nantinya. Tiga kemampuan yang dimaksudkan adalah (1) Visual / Penglihatan, melalui melihat siswa diharapkan dapat belajar maksimal dan memahami materi yang diberikan guru; (2) Auditorial / Mendengar, melalui mendengarkan penjelasan guru siswa mampu menyerap dan memahami materi yang dijelaskan guru; (3) Kinestetik / Melakukan (bergerak, bekerja, menyentuh), dengan terlibat langsung dalam IPA misalnya praktikum dengan siswa terlibat langsung dengan objek diharapkan siswa dapat lebih memahami materi pembelajaran yang diajarkan guru. Karena ketiga kemampuan tersebut memang telah dimiliki dalam diri siswa masing-masing kini guru hanya perlu memaksimalkan ketiga organ tubuh yang bersangkutan dan tidak perlu menggunakan sarana dan prasarana yang khusus. Hal tersebut akan sedikit tidaknya mempermudah pekerjaan guru. Hal itu pula yang membuat penulis tertarik mengunakan model pembelajaran Visual, Aditorial, Kinestetik (VAK).

Dalam proses pembelajaran kehadiran media mempunyai arti yang cukup penting, karena ketidakjelasan materi yang disampaikan dapat dibantu dengan media. Penggunaan media pembelajaran sangat besar perannya. Penyampaian materi dari guru kepada siswa akan lebih mudah dilaksanakan dengan menggunakan media. Media pembelajaran terdiri dari dua kata, yaitu media dan pembelajaran. Menurut Cecep dan Sutjipto (2016: 22) media pembelajaran adalah sarana untuk meningkatkan kegiatan proses belajar mengajar mengingat banyaknya bentuk-bentuk media tersebut, maka guru harus dapat memilihnya dengan cermat, sehingga dapat digunakan dengan tepat. Salah satu media yang digunakan dalam proses pembelajaran Visualization, Auditory, Kinestetic (VAK) meningkatkan minat belajar siswa 
yaitu salah satunya Media gambar. Menurut Susilana dan Cepi Riyana, (2009:16) menyatakan bahwa media gambar adalah media visual yang berupa gambar yang dihasilkan melalui proses fotografi.

Pendidikan yang menerapkan model pembelajaran yang inovatif dan didukung dengan pemanfaatan media sebagai perantara pesan dapat mengoptimalkan hasil belajar siswa dan membuat siwa lebih aktif serta dapat berinteraksi dengan sumber belajar. Sehingga pembelajaran tidak akan terpusat pada penjelasan guru. Berdasarkan paparan di atas, muncullah ketertarikan untuk menerapkan Model Pembelajaran Visualization, Auditory, Kinestetic (VAK) berbantuan media Gambar dan melihat pengaruhnya terhadap hasil belajar siswa kelas V SD di Gugus 2 Banjarangkan Kabupaten Klungkung untuk menilai ada tidaknya pengaruh dari siswa yang dibelajarkan dengan menggunakan model menerapkan Model Pembelajaran Visualization, Auditory, Kinestetic (VAK) berbantuan media Gambar dan siswa yang dibelajarkan dengan menggunakan pembelajaran tanpa model.

Berdasarkan uraian tersebut, maka dilaksanakan penelitian tentang model pembelajaran Visualization, Auditory, Kinestetic (VAK) berbantuan media Gambar Terhadap Hasil Belajar Siswa Kelas V SD Di Gugus 2 Banjarangkan Kabupaten Klungkung Tahun Pelajaran 2017/2018”.

\section{Metode}

Pelaksanaan penelitian ini di Gugus 2 Banjarangkan Kabupaten Klungkung. Penelitian ini dilaksanakan pada rentangan waktu 30 Maret 2018 sampai dengan 27 April 2018 pada tahun pelajaran 2017/2018. Pelaksanaan penelitian ini dilakukan sesuai dengan jadwal kurikuler sekolah, terutama pada pembelajaran IPA di kelas V dengan siswa berjumlah 63 orang. Populasi penelitian ini adalah siswa kelas V di Gugus 2 Banjarangkan dan sampel penelitian adalah SD Negeri 2 Banjarangkan sebagai kelompok eksperimen dan SD Negeri 3 Banjarangkan sebagai kelompok kontrol. Jenis penelitian ini adalah penelitian eksperimen semu. Penelitian eksperimen adalah suatu penelitian yang dilakukan oleh guru untuk mengetahui pengaruh suatu model pembelajaran terhadap proses pembelajaran dengan tujuan untuk memperbaiki dan menyempurnakan proses pembelajaran. Variabel yang digunakan dalam penelitian ini ada dua, yaitu variabel bebas dan variabel terikat. Variabel bebas dalam penelitian ini adalah Model Pembelajaran Visualization, Auditory, Kinestetic (VAK) berbantuan media Gambar, dan variabel terikatnya adalah hasl belajar IPA.

Rancangan penelitian yang di gunakan adalah Non-Equivalent Post-test Only Control Group Design, Prosedurnya dapat dilihat pada tabel 0.1 .

Tabel 0.1. Rancangan Penelitian Post Test Only Control Group Design

\begin{tabular}{lll}
\hline Kelompok & Perlakuan & Tes akhir (Post-test) \\
\hline $\mathrm{KE}$ & $\mathrm{X}$ & $\mathrm{O}_{1}$ \\
$\mathrm{KK}$ & - & $\mathrm{O}_{2}$ \\
\hline
\end{tabular}

(dimodifikasi dari Agung, 2014:75)

Keterangan:

$\mathrm{KE} \quad=$ Kelompok Eksperimen

$\mathrm{KK}=$ Kelompok Kontrol

$\mathrm{X}=$ Perlakuan, yaitu pengaruh model pembelajaran Visualization, Auditory, Kinestetic

(VAK) berbantuan media gambar.

- $\quad=$ Tidak mendapatkan perlakuan

$O_{1} \quad=$ Post-test untuk kelompok eksperimen

$\mathrm{O}_{2} \quad$ = Post-test untuk kelompok kontrol

Metode pengumpulan data dalam penelitian ini adalah metode tes. Menurut Sudijono (2005: 67), Tes adalah cara atau prosedur dalam rangka pengukuran dan penilaian di bidang pendidikan, yang berbentuk pemberian tugas atau serangkaian tugas (baik berupa pertanyaan-pertanyaan yang harus dijawab), atau perintah-perintah (yang harus dikerjakan) oleh testee. Teknik yang digunakan untuk mecari hasil belajar IPA siswa adalah dengan mengadakan tes hasil belajar. Instrument yang digunakan dalam mencari hasil belajar siswa adalah tes objektif dengan jumlah 30 butir soal. Namun, sebelum soal diberikan pada siswa sebagai soal post-test perlu terlebih dahulu dilakukan uji judgest, uji validitas, uji reliabilitas, uji taraf kesukaran dan uji daya beda. Maka dari itu meskipun dalam penelitian nantinya 
hanya menggunakan 30 butir soal, soal yang dirancang yang akan melewati beberapa uji jumlahnya sedikit lebih banyak yaitu 40 butir soal.

Uji judgest dilakukan oleh dua orang ahli yang membidangi mata pelajaran IPA. Dalam uji judgest dilakukan beberapa kali revisi terhadap soal yang dibuat. Setelah melewati uji judgest soal kemudian diuji cobakan pada siswa. Dari hasil uji coba akan dilakukan uji validitas, reliabilitas, taraf kesukaran tes, dan daya beda tes. Dari hasil uji validitas ada 7 soal yang dinyatakan tidak valid. Dari uji taraf kesukaran instrumen yang dibuat tergolong dalam kategori sukar. Sedangkan dari uji daya beda tes yang dilakukan ada 3 soal yang harus dibuang, secara tidak sengaja soal yang harus dibuang juga merupakan soal yang dinyatakan tidak valid, sehingga soal yang akan dijadikan sebagai post-test hanya 30 soal.

Data yang diperoleh dari post-test yang diberikan pada siswa selanjutnya dianalisis dengan teknik analisis deskriptif dan analisis prasyarat. Teknik analisis deskriptif yang dicari berupa mean, median, modus, varians, dan standar deviasi (SD) dan analisis prasyarat yang dicari berupa uji normalitas, uji homogenitas, dan Terakhir dilakukan pengujian hipotesis, Rumus uji-t yang digunakan adalah polled varians. Namun, sebelum dilakukan uji hipotesis, terlebih dahulu dilakukan uji prasyarat berupa uji normalitas sebaran data dan uji homogenitas varians. Uji normalitas sebaran data dilakukan dengan rumus chi-kuadrat dengan kriteria pengujian data berdistribusi normal jika $\chi^{2}$ hitung $<\chi^{2}$ tabel, dengan taraf signifikansi 5\%. Sedangkan uji homogenitas varians dihitung dengan uji-F dengan kriteria pengujian adalah kedua populasi memiliki varians yang berbeda jika $\mathrm{F}_{\text {hitung }}>\mathrm{F}_{\text {tabel }}$ pada taraf signifikansi $5 \%$.

\section{Hasil Dan Pembahasan}

Penelitian dilaksanakan 8 kali pertemuan dapat dilihat pada 7 Rencana Pelaksanaan Pembelajaran (RPP). data yang dianalisis dalam penelitian ini adalah data hasil belajar IPA yang diperoleh melalui posttest terhadap 32 orang siswa menunjukkan bahwa skor tertinggi adalah 28 dan skor terendah adalah 19. Data hasil belajar IPA kelompok eksperimen dapat dilihat pada tabel 0.1 berikut ini.

Tabel 01 hasil belajar IPA kelompok Eksperimen

\begin{tabular}{llllll}
\hline Interval & $(\mathbf{X})$ & (f) & $\begin{array}{l}\text { Frekuensi } \\
\text { relative }\end{array}$ & FK & $\mathbf{f ( X )}$ \\
\hline $19-20$ & & & & & \\
$21-22$ & 19,5 & 3 & 9,375 & 3 & 58,5 \\
$23-24$ & 21,5 & 7 & 21,875 & 10 & 150.5 \\
$25-26$ & 23,5 & 8 & 25 & 18 & 188 \\
$27-28$ & 25,5 & 9 & 28,125 & 27 & 229.5 \\
\hline Jumlah & 27,5 & 5 & 15,625 & 32 & 137.5 \\
\hline
\end{tabular}

Penelitian dilaksanakan 8 kali pertemuan dapat dilihat pada 7 Rencana Pelaksanaan Pembelajaran (RPP). data yang dianalisis dalam penelitian ini adalah data hasil belajar IPA yang diperoleh melalui posttest terhadap 31 orang siswa menunjukkan bahwa skor tertinggi adalah 22 dan skor terendah adalah 14. Data hasil belajar IPA kelompok control dapat dilihat pada tabel 0.2 berikut ini.

Tabel 02 hasil belajar IPA kelompok kontrol

\begin{tabular}{llllll}
\hline Interval & $(\mathbf{X )}$ & $\mathbf{f}(\mathbf{f})$ & $\begin{array}{l}\text { Frekuensi } \\
\text { relative }\end{array}$ & $\mathbf{F K}$ & $\mathbf{f ( X )}$ \\
\hline $19-20$ & 19,5 & 3 & 9,375 & 3 & 58,5 \\
$21-22$ & 21,5 & 7 & 21,875 & 10 & 150.5 \\
$23-24$ & 23,5 & 8 & 25 & 18 & 188 \\
$25-26$ & 25,5 & 9 & 28,125 & 27 & 229.5 \\
$27-28$ & 27,5 & 5 & 15,625 & 32 & 137.5 \\
\hline Jumlah & $\mathbf{1 1 7 , 5}$ & $\mathbf{3 2}$ & $\mathbf{1 0 0}$ & & $\mathbf{7 6 4}$ \\
\hline
\end{tabular}


Uji normalitas dianalisis dengan chi-khuadrat. diperoleh harga $X_{\text {hitung }}^{2}$ hasil pos-test kelompok eksperimen sebesar 0,97 dan $X^{2}$ tabel dengan derajat kebebasan $\mathrm{dk}=2$ pada taraf signifikan 5\% adalah 5,59. Hal ini berarti $x^{2}$ hitung hasil post-test kelompok eksperimen lebih kecil dari $x^{2}$ tabel $(0,97<5,59)$. Sehingga data hasil post-test kelompok eksperimen berdistribusi normal. Sedangkan diperoleh harga $x^{2}$ hitung hasil post-test kelompok kontrol sebesar 3,03 dan $x^{2}$ tabel dengan derajat kebebasan $\mathrm{dk}=2$ pada taraf signifikan $5 \%$ adalah 5,59. Hal ini berarti $x^{2}$ hitung hasil post-test kelompok kontrol lebih kecil dari $x^{2}$ tabel $(3,03<5,59)$. Sehingga data hasil post-test kelompok kontrol berdistribusi normal.

Uji homogenitas varians dilakukan terhadap varians pasangan antar kelompok eksperimen dengan kelompok kontrol. Uji yang digunakan adalah uji $\mathrm{F}$ dengan kriteria data dan homogen jika $\mathrm{F}_{\text {hitung }}<\mathrm{F}_{\text {tabel. }}$ $\mathrm{F}_{\text {hitung }}$ sebesar 1,13. sedangkan $\mathrm{F}_{\text {tabel }}$ dengan $\mathrm{db}_{\text {pembilang }}=31$ dan $\mathrm{db}_{\text {penyebut }}=30$ pada taraf signifikan $5 \%$ adalah 5,59. Hal ini berarti $F_{\text {hitung }}$ lebih kecil dari pada $F_{\text {tabel }}(1,13<5,59)$ sehingga dapat dinyatakan bahwa varians data hasil post-test kelompok eksperimen dan kontrol adalah homogen $\left(\mathrm{H}_{0}\right.$ diterima). Berdasarkan perhitungan didapatkan $\mathrm{F}_{\text {hitung }}<\mathrm{F}_{\text {tabel }}(1,13<5,59)$ yang berarti dapat disimpulkan bahwa data post-test kedua kelas homogen.

Berdasarkan hasil uji prasyarat analisis, diperoleh bahwa hasil pos-test kelompok eksperimen dan kelompok kontrol memiliki distribusi normal dan memiliki varians yang homogen. Selain itu, jumlah sampel kelompok eksperimen tidak sama dengan kelompok kontrol. Oleh karena itu dalam uji hipotesis digunakan analisis uji t (t-test) sampel berkorelasi dengan rumus poled varians. Kreteria pengujianya adalah $\mathrm{H}_{0}$ ditolak jika $\mathrm{t}_{\text {hitung }}>\mathrm{t}_{\text {tabel }}$ pengujian dilakukan pada taraf signifikasi $5 \%$ dengan drajat kebebasan $\mathrm{db}=\mathrm{n}_{1}+\mathrm{n}_{2}-2$.

Hasil analisis Uji-t dengan rumus poled varians diperoleh $t_{\text {hitung }}$ sebesar 7,8687 sedangkan $t_{\text {tabel }}$ dengan $\mathrm{db}=61$ pada taraf signifikasi $5 \%$ adalah 1,999. Hasil perhitungan menunjukkan bahwa $t_{\text {hitung }}>$ $t_{\text {tabel }}$ yang terlihat dari $t_{\text {hitung }}(7,8687)$ lebih besar dari $t_{\text {tabel }}(1,999)$ sehingga $H_{0}$ ditolak dan $H_{1}$ diterima. Maka dari itu dapat di tarik kesimpulan bahwa terdapat perbedaan hasil belajar IPA antara kelompok siswa yang mengikuti pembelajaran dengan menerapkan pembelajaran model Visualization, Auditory, Kinestetic (VAK) berbantuan media gambar dan kelompok siswa yang mengikuti pembelajaran dengan menerapkan pembelajaran tanpa model pada siswa kelas V SD Gugus 2 Banjarangkan Kabupaten Klungkung.

Berdasarkan deskripsi data hasil penelitian, menunjukan bahwa terdapat perbedaan hasil belajar antara kelompok siswa yang dibelajarkan dengan model Visualization, Auditory, Kinestetic (VAK) berbantuan media gambar dan kelompok siswa yang dibelajarkan dengan menggunakan pembelajaran tanpa model pada siswa kelas V Semester Genap di Gugus 2 Banjarangkan Kabupaten Klungkung Tahun Pelajaran 2017/2018. Secara deskriptif, hasil belajar IPA siswa kelompok eksperimen lebih tinggi dibandingkan dengan siswa kelompok kontrol. Tinjauan ini berdasarkan pada rata-rata skor hasil belajar IPA siswa dan uji t. Rata-rata skor hasil belajar IPA siswa yang dibelajarkan dengan model Visualization, Auditory, Kinestetic (VAK) berbantuan media gambar berada pada kategori sangat tinggi sedangkan skor hasil belajar IPA siswa yang dibelajarkan dengan pembelajaran tanpa model berada pada kategori sedang. Berdasarkan hasil analisis menggunakan uji t diperoleh $t_{\text {hitung }}$ 7,8687 dan $t_{\text {tabel }} 1,999$ untuk db 61 dengan taraf signifikan $5 \%$. Hasil perhitungan tersebut menunjukan bahwa $t_{\text {hitung }}>t_{\text {tabel }}$ sehingga $\mathrm{H}_{0}$ ditolak dan $\mathrm{H}_{1}$ diterima. Adanya perbedaan yang menunjukkan bahwa model Visualization, Auditory, Kinestetic (VAK) berbantuan media gambar berpengaruh terhadap hasil belajar IPA siswa kelas V di Gugus 2 Banjarangkan Kabupaten Klungkung Tahun Pelajaran 2017/2018.

Perbedaan yang hasil belajar IPA antara kelompok siswa yang dibelajarkan dengan model Visualization, Auditory, Kinestetic (VAK) berbantuan media gambar dan kelompok siswa yang dibelajarkan dengan pembelajaran tanpa model. Pertama, pada kelompok siswa yang menggunakan model pembelajaran Visualization, Auditory, Kinestetic (VAK) berbantuan media gambar mampu melatih dan mengembangkan potensi siswa yang telah dimiliki oleh pribadi masing-masing siswa akan lebih senang mengikuti pembelajaran secara berkelompok mengggunakan media gambar-gambar yang konkret dan menarik, dengan seperti ini siswa lebih mudah dalam menyelesaikan permasalahan karena adanya interaksi antara siswa satu dengan siswa lainnya sehingga dapat meningkatkan hasil belajar siswa. mampu melibatkan siswa secara maksimal dalam menemukan dan memahami suatu konsep melalui kegiatan fisik, seperti demontrasi, percobaan, observasi, dan diskusi aktif. Pembelajaran dengan model pembelajaran Visualization, Auditory, Kinestetic (VAK) berbantuan media gambar memberikan kesempatan bagi siswa untuk berlatih secara mandiri melalui umpan balik dari teman atau guru. Pembelajaran ini membuat siswa antusias bekerja sama dengan kelompoknya dan melalukan percobaan secara langsung dan bisa untuk saling berbagi informasi secara bersamaan. Deporter (dalam Shoimin,2014:226), VAK merupakan tiga modalitas yang dimiliki oleh setiap manusia. Ketiga modalitas 
tersebut kemudian dikenal sebagai gaya belajar. Gaya belajar merupakan kombinasi dari bagaimana seseorang dapat menyerap dan kemudian mengatur serta mengolah informasi. Dalam hal ini, guru sangat berperan penting untuk membimbing siswa melakukan diskusi dan percobaan secara langsung, sehingga terciptanya suasana belajar yang kondusif, aktif, kreatif dan menyenangkan.

Kedua, pada kelompok siswa yang menggunakan model pembelajaran Visualization, Auditory, Kinestetic (VAK) berbantuan media gambar siswa lebih berani dan percaya diri dalam pembelajaran. Siswa lebih berani untuk bertanya baik dengan teman maupun dengan guru mengenai pendapat atau kurang pahamnya terhadap suatu persoalan. Dengan bertanya dan berani menyampaikan pendapat siswa sudah menunjukkan keaktifan dalam pembelajaran. Hal tersebut membuat siswa memiliki pengetahuan yang lebih luas tentang materi yang disajikan sehingga hasil belajar siswa meningkat.

Ketiga, pemberian pujian, penghargaan berupa pujian maupun tepuk sukses sangat berpengauh terhadap tingginya semangat dan minat siswa dalam proses pembelajaran. Adanya semangat, minat, dan ketertarikan siswa mengakibatkan materi yang disampaikan oleh guru akan mudah dipahami oleh siswa, sehingga berpengaruh terhadap hasil belajar siswa.

Berbeda halnya dengan pembelajaran tanpa model. Pertama, saat pembelajaran kelas kontrol, peran guru sangat mempengaruhi meningkatnya rata-rata hasil belajar siswa. Kedua, Dalam pembelajaran, guru lebih banyak mendominasi kegiatan pembelajaran sehingga pembelajaran hanya berpusat pada guru. Ketiga, Hal tersebut mengakibatkan siswa pasif dan hanya mendengarkan apa yang dijelaskan oleh guru tanpa berusaha untuk menemukan sendiri konsep-konsep yang dipelajari. Pembelajaran yang demikian kurang memberikan pengalaman dan tantangan baru bagi siswa sehingga siswa merasa cepat bosan, hal tersebut dapat mengurangi minat siswa untuk belajar. Pada akhirnya akan mengakibatkan hasil belajar siswa menjadi kurang masksimal.

Berdasarkan paparan di atas, dapat dinyatakan bahwa pembelajaran dengan menggunakan model pembelajaran Visualization, Auditory, Kinestetic (VAK) berbantuan media gambar mampu meningkatkan minat dan motivasi belajar siswa, sehingga berpengaruh terhadap hasil belajar IPA siswa kelas V SD di Gugus 2 Banjarangkan, Kabupaten Klungkung tahun pelajaran 2017/2018. Maka dari itu, pembelajaran ini dapat diterapkan sebagai variasi dalam kegiatan pembelajaran sehingga siswa tidak mudah jenuh, dan pembelajaran menjadi lebih variatif. Akhirnya, hasil belajar pun dapat dioptimalkan.

\section{Simpulan Dan Saran}

Berdasarkan rumusan masalah dan hasil penelitian, maka simpulan dalam penelitian ini adalah terdapat perbedaan Hasil Belajar IPA antara siswa yang dibelajarkan model pembelajaran Visualization, Auditory, Kinestetic (VAK) berbantuan media gambar dengan kelompok siswa yang tidak dibelajarkan menggunakan model pembelajaran Visualization, Auditory, Kinestetic (VAK) berbantuan media gambar di Gugus 2 Banjarangkan Kabupaten Klungkung Tahun Pelajaran 2017/2018. Hal ini ditunjukkan pada hasil hipotesis uji-t yang diketahui bahwa $t_{\text {hitung }}=7,8687>t_{\text {tabel }}=1,999$ berarti $\mathrm{H}_{0}$ ditolak dan $\mathrm{H}_{1}$ diterima. Hal ini berarti terdapat perbedaan keterampilan berbicara bahasa terdapat perbedaan hasil belajar IPA antara kelompok siswa yang mengikuti pembelajaran dengan menerapkan pembelajaran model Visualization, Auditory, Kinestetic (VAK) berbantuan media gambar dan kelompok siswa yang mengikuti pembelajaran dengan menerapkan pembelajaran tanpa model pada siswa kelas V SD Gugus 2 Banjarangkan Kabupaten Klungkung.

Berdasarkan simpulan di atas dapat di sarankan beberapa hal yaitu: 1) Peserta didik hendaknya mempertahankan semangat, keaktifan dan rasa percaya dirinya dalam mengikuti proses pembelajaran lainnya. 2) Guru hendaknya mencoba mengembangkan kompetensinya dalam hal mengelola pembelajaran untuk mewujudkan kegiatan pembelajaran yang menyenangkan, efektif, dan mampu meningkatkan hasil belajar siswa. 3) Kepala sekolah hendaknya mengajak guru-guru untuk mengikuti seminar atau pelatihan mengenai upaya meningkatkan hasil belajar siswa dengan menggunakan model pembelajaran yang inovatif. Dan 4) Peneliti lain, dengan dilakukannya penelitian ini masalah di SD khususnya di dalam proses pembelajaran bisa dipecahkan dan di cari jalan keluarnya sehingga proses pembelajaran berlangsung secara optimal dan tercapainya tujuan pembelajaran.

\section{Daftar Rujukan}

Adnyani, N. L. S., Renda, N. T., \& Kusmariyatni, N. 2014. "Pengaruh Model Vak Berbantuan Lingkungan Terhadap Hasil Belajar Ipa Siswa Kelas V Sd Gugus Mas". e-Journal MIMBAR PGSD Universitas Pendidikan Ganesha Jurusan PGSD, Vol. 2, No. 1 Tahun 2014. 
Agung, A. A. Gede. 2014. Metodelogi Penelitian Pendidikan. Yogjakarta: Aditya Media Publishing.

Kustandi Cecep, Sutjipto Bambang.2016. Media Pembelajaran. Bogor: Ghalia Indonesia.

Koyan, I W. 2012.Statistik Pendidikan "Teknik Analisis Data Kuantitatif". Singaraja: Universitas Pendidikan Ganesha Press.

Susilana, Rudi dan Cepi Riyana. 2009. Media Pembelajaran. Bandung : Cv Wacana Prima.

Shoimin, Aris. 2014. 68 Model Pembelajaran Inovatif Dalam Kurikulum 2013. Yogjakarta: AR-RUZZ MEDIA.

Sudijono, Anas. 2005. Pengantar Evaluasi Pendidikan. Jakarta: PT Raja Grafindo Persada.

Susanto, Ahmad. 2013. Teori Belajar dan Pembelajaran di Sekolah Dasar.Jakarta: PT Fajar Interpratama Mandiri. 